ваності, виявити можливість зниження витрат, відкоригувати облік i, що найважливіше, мінімізувати податкові ризики.

1. Букало Н.А. Інвентаризація як умова для складання фінансової звітності / Н.А. Букало // Економічний аналіз: зб. наук. праць. - Тернопіль: Видавничополіграфічний центр ТНЕУ «Економічна думка», 2016. - Том 23. - № 1. - С. 167-173.

2. Закон України «Про бухгалтерський облік та фінансову звітність в Україні» від 16.07.1999 р. № 996-XIV.

3. Кузьмін Дм.Л. Суб'єкти інвентаризації та порядок їх формування / Дм.Л. Кузьмін // Міжнародний збірник наукових праць. - Випуск 1(13). - С. 203-210.

4. Олійник С.О. Інвентаризація в системі бухгалтерського обліку та напрями іiі вдосконалення / Олійник С.O. // INNOVATIVE SOLUTIONS IN MODERN SCIENCE - 2017. - № 5(14).

5. Податковий кодекс України від 02.12.2010p. №2755-VI.

6. Положення про інвентаризацію активів та зобов'язань, затверджено наказом Міністерства фінансів України від 02.09.2014 р. № 879.

7. Порядок подання фінансової звітності, затверджено Постановою КМУ від 28.02.2000 p. № 419 .

8. Харламова О.В. Особливості інвентаризації для цілей складання МСФЗзвітності [Електронний ресурс] / О.В. Харламова - Режим доступу: http://www.vestnik-econom.mgu.od.ua/journal/2015/11-2015/65.pdf.

9. Шнурко А.М. Особливості проведення інвентаризації на підприємстві [Електронний ресурс] / А.М. Шнурко, М.О. Бражко. - Режим доступу: http://www.sworld.com.ua/konfer37/738.pdf.

*УДК 336.77.067

Чиж Н.М., к.е.н., доцент

Дзямулич M.I., к.е.н., доцент

Потьомкіна О.В., к.е.н., доцент

Луцький національний технічний університет

\title{
ОСОБЛИВОСТІ ФОРМУВАННЯ РЕСУРСНОЇ БАЗИ БАНКІВ УКРАЇНИ
}

У статті досліджено особливості формування ресурсної бази банківських установ. Проаналізовано динаміку та сучасний стан, а також умови формування ресурсного забезпечення банків в Україні. Визначена роль коштів фізичних та юридичних осіб у формування ресурсної бази банку.

* Чиж Н.М., Дзямулич М.I., Потьомкіна О.В. 
Ключові слова: банк, капітал, зобов'язання, фінансові ресурси, джерела формування ресурсів банку, ресурсна база.

\section{Chyzh N., Dzyamulich M., Potemkina O. FEATURES OF FORMATION OF THE RESOURCE BASE OF BANKS OF UKRAINE}

In the article the features of formation of resource base of banking institutions are investigated. The dynamics and current state, as well as the conditions for the formation of resource provision of banks in Ukraine are analyzed. The role of funds of individuals and legal entities in forming the resource base of the bank is determined.

Effective functioning of the bank is possible only with the availability of an appropriate resource base, which helps to achieve the main goal of banking activity, which is to minimize costs and maximize profits through active and passive operations. For most banking institutions, sufficient resources provide the ability to maintain liquidity, solvency, reliability, profitability, as well as to neutralize certain risks specific to the banking sector.

The formation of commercial banks' resources in a sufficient amount is of great importance for the effective operation of banking institutions and the development of the banking system as a whole. Having sufficient financial resources allows you to carry out active banking operations in order to obtain the maximum level of profit and differentiation of risks. The main of the active operations of commercial banks is lending to economic agents, including long-term ones. Long-term loans can only be provided by financially stable banks that have the ability to seize the available resources for a long time.

Today, the formation of the resource base of commercial banks is one of the most important tasks for ensuring economic growth. The banking system must have a set of resources sufficient to lend to current needs of economic entities, as well as to finance investment activities, to create appropriate reserves and maintain its own liquidity. The volume of financial resources determines their demand in the financial market and directly affects the size of interest rates in both passive and active operations.

The structure of the resources of commercial banks is individual and depends on the degree of their specialization, the peculiarities of their activities, the state of the market of credit resources and other factors. For the transition of the Ukrainian economy to a new state, a significant increase in both the capital of the banking system and resources in general is required.

At the initial stage, the acceleration of the current liabilities should be accelerating as a result of the development of entrepreneurial activity, and subsequently, with the increase of incomes both business entities and the population, the structure of borrowed funds will change with the increase of the share of time resources, first of all deposits of the population. This consistency should provide Ukraine and its banking system with a self-sufficient resource base for economic growth.

So, after analyzing the formation of resource provision of banks in Ukraine, the role of deposits in the formation of the bank's resource base is determined. Since population deposits are the cheapest source of attracted banks, it is important to implement 
and extend the practice of cashless settlements between individuals and to realize such a function of money as accumulation through investing them in accounts with banks. At the same time, it is important to overcome the distrust of the banking system by the Ukrainian population, which will help improve the market conditions for the effective functioning of banks.

Key words: bank, capital, liabilities, financial resources, sources of bank resources formation, resource base.

\section{Чиж Н.М., Дзямулич М.И. Потемкина О.В. \\ ОСОБЕННОСТИ ФОРМИРОВАНИЯ РЕСУРСНОЙ БАЗЫ БАНКОВ УКРАИНЫ}

В статье исследованы особенности формирования ресурсной базы банковских учреждений. Проанализирована динамика и современное состояние, а также условия формирования ресурсного обеспечения банков в Украине. Определенная роль средств физических и юридических лиц в формирование ресурсной базы банка.

Ключевые слова: банк, капитал, обязательства, финансовые ресурсы, источники формирования ресурсов банка, ресурсная база.

Постановка проблеми у загальному вигляді та її зв'язок 3 важливими науковими та практичними завданнями. Ефективне функціонування комерційного банку можливе лише за наявності відповідної ресурсної бази, яка сприяє досягати основну мету банківської діяльності, що полягає у мінімізації витрат та максимізації прибутку за рахунок активних та пасивних операцій. Для більшості вітчизняних банківських установ достатня кількість ресурсів дає можливість підтримувати на відповідному рівні ліквідність, платоспроможність, надійність, рентабельність, дотримуватись економічних нормативів, а також нейтралізувати певні ризики, що притаманні банківському сектору.

Аналіз останніх досліджень, у яких започатковано вирішення проблеми. Особливу увагу дослідженням достатності ресурсної бази приділяють: М. Алексеєнко, О. Барановський, А. Гальчинський, М. Савлук, Т. Смовженко, В. Коваленко, А. Мороз, В. Міщенко, І. Ларіонова, О. Лаврушин, П. Роуза, Дж. Сінкі мл., Д. Розенберга, Е. Долана та інших. Зважуючи га грунтовні дослідження провідних вітчизняних та зарубіжних вчених, що стосуються ефективності формування ресурсної бази банків, зазначена проблема й дотепер лишається однією з найактуальніших. 
Цілі статті. Метою написання даної статті є дослідження основних джерел фінансових ресурсів банків та обгрунтування перспективних напрямів зростання ресурсної бази вітчизняних банків у сучасним умовах господарювання в Україні.

\section{Виклад основного матеріалу дослідження 3 обгрунтуван-} ням отриманих наукових результатів. Наявність постійної конкуренції в банківській діяльності зумовлює розвиток та удосконалення як самої банківської системи, так і окремих її ланок - комерційних банків. Для успішної діяльності на фінансовому ринку вітчизняні банки використовують не тільки власний капітал, але й залучений та позичений, котрі становлять левову частку у структурі капіталу кожного банку.

Мишкін Ф. зазначає, що не вигідно нагромаджувати занадто багато капіталу, оскільки це впливає на розмір доходу акціонерів. Так, при отриманні чистого прибутку у розмірі 1 млн. грошових одиниць при сумі активів 100 млн. грошових одиниць, якщо власний капітал становить $10 \%$, то акціонери отримують дохід у розміpi $10 \%$, а якщо власний капітал - 5\%, дохід акціонера - $20 \%$ відповідно [4].

Цікаву точку зору щодо необхідності та доцільності залучення банком коштів для здійснення своєї діяльності мали класики політичної економіки. Так, Д. Рікардо говорив, що »власне функції банкіра починаються тільки з того моменту, коли він утилізує чужі гроші. Поки він оперує тільки власними коштами, він лише капіталіст. Діяльність такого банкіра була б вузькою, і таке підприємство не було б банком» [2].

Ресурсна база банку являє собою комплексне поняття, котре відображає систему показників, що характеризують наявність, розміщення і використання фінансових ресурсів. Фінансові ресурси кожного банку мають певну структуру, тобто співвідношення між власними коштами та зобов'язаннями банку, що складається під впливом конкретних умов: універсалізації чи спеціалізації банку, його кредитної стратегії й тактики, обсягу послуг, які пропонують клієнтам, і, звичайно, стану економіки країни.

Забезпечення оптимального співвідношення між власними, залученими та запозиченими коштами є особливо важливим в умовах дефіциту фінансових ресурсів. 
Формування ресурсів комерційних банків в достатньому обсязі має велике значення для ефективної діяльності банківських установ та розвитку банківської системи в цілому. Наявність достатнього обсягу фінансових ресурсів дозволяє здійснювати активні банківські операції з метою отримання максимального рівня прибутку і диференціації ризиків. Основною з активних операцій комерційних банків є кредитування суб'єктів економічних відносин, в тому числі й довгострокове. Надавати довгострокові кредити можуть лише фінансово стійкі банки, які мають можливість тривалого вилучення наявних ресурсів.

Нині формування ресурсної бази комерційних банків є одним iз найважливіших завдань для забезпечення економічного зростання. Банківська система має володіти сукупністю ресурсів, достатніх як для кредитування поточних потреб суб'єктів господарської діяльності, так і для фінансування інвестиційної діяльності, формування відповідних резервів і підтримки власної ліквідності. Обсяг фінансових ресурсів визначає їхній попит на фінансовому ринку й безпосередньо впливає на розмір процентних ставок як за пасивними, так і за активними операціями [2, с. 60].

Сукупний обсяг зобов'язань українських банків протягом 2017 року зріс на 3,5 \% до 1173 млрд. грн. Аналізуючи дані таблиці 1, видно, що основними складовими зобов'язань банківської системи України є кошти фізичних та юридичних осіб. Варто відзначити, що кошти фізичних осіб є головним джерелом формування банківських ресурсів. Це підтверджує той факт, що станом на 1 січня 2018 року кошти фізичних осіб становили 479 млрд. грн, що на 42 млрд. грн більше ніж в 2015 році або зросли на 9,6\%. Для коштів фізичних осіб, теж прослідковується позитивна тенденція збільшення їх розміру на 10 млрд. грн або на 2,7 5 для даного періоду .

Протягом 2017 року сукупний обсяг клієнтського портфелю банківської системи України збільшився на 6,4\% та станом на 01.01.2018 р. відповідав 858,4 млрд. грн. Незважаючи на визнання неплатоспроможними ряду банківських установ, їх вплив на загальний обсяг зобов'язань був незначним, оскільки депозитний портфель цих установ був дуже малим. За строковим характером в клієнтському портфелі переважають короткострокові депозитні 
вклади строком до 1 року, включаючи кошти на вимогу. Слід зауважити, що в 2017 році депозитний ринок почав демонструвати ознаки відновлення, обсяг залучених депозитів в цьому році вперше за останні декілька років показує зростання.

3 початку 2017 року встановилася тенденція до зростання обсягу вкладів на вимогу. Станом на 01.01.2018 р. їх сума відповідає 438,3 млрд. грн., що дорівнює 47\% сукупного портфелю коштів клієнтів (43\% на початок 2017 року). Слід зауважити, що частка коштів, залучених на строк 1-2 роки, поступово зростає, проте загальний їх вклад у сукупний показник $є$ незначним [1].

Клієнтський портфель суб'єктів господарської діяльності протягом 2017 р. збільшився на 3,6\% (40,2 млрд. грн.) та станом на 01.01.2018 р. складав 379,8 млрд. грн. При цьому, нарощення коштів суб'єктів господарської діяльності відбувалося як за рахунок збільшення залишків на поточних рахунках, так і строкових коштів. На динаміку показника знаний вплив мають курсові різниці. Разом 3 тим, даний сегмент також демонструє ознаки поступового «оздоровлення», що виражається в збільшенні коштів суб'єктів господарської діяльності на рахунках (за підсумками 2017 року (271,6 млрд. грн.), або +1,6 млрд. грн).

Варто відзначити, що структура ресурсів окремих комерційних банків є індивідуальною і залежить від ступеня їх спеціалізації, особливостей їх діяльності, стану ринку кредитних ресурсів та інших факторів. Так, універсальні комерційні банки, які здійснюють переважно операції 3 короткострокового кредитування, як основний вид залучених ресурсів використовують короткотермінові депозити, а іпотечні банки, які займаються довгостроковим кредитуванням під заклад нерухомості, мобілізують кошти шляхом випуску та реалізації довгострокових зобов'язань.

Висновки. Отже, провівши аналіз формування ресурсного забезпечення банків в Україні, визначена вагому роль депозитів у формування ресурсної бази банку. Оскільки вклади населення є найбільш дешевим залученим ресурсом банків, важливим $є$ втілення та поширення практики безготівкових розрахунків між фізичними особами та реалізація такої функції грошей як накопичення через вкладення їх на рахунки в банки. А для цього необхідно удосконалити нормативну базу, яка регулює дані відносини. При цьо- 
му важливим є подолання недовіри до банківської системи з боку населення України, що сприятиме покращенню умов на ринку для ефективної діяльності банків. А це дасть ще більший результат, виражений у економічному зростанні держави, який є вигідним для всіх суб'єктів господарювання, в тому числі, і для комерційних банків.

1. Аналітичний огляд банківської системи України за 2017 рік / [Електронний pecypc]. - Режим доступу: http://rurik.com.ua/documents/research/bank_ system_2017.pdf.

2. Васюренко О. Ресурсний потенціал комерційного банку// Банківська справа. 2002. - № 1. - С. 58-64

3. Долан Э. Дж. Деньги, банковское дело и денежно-кредитная политика : пер. с англ. / Долан Дж. Э., Кэмпбэлл К. Д., Кэмпбэлл Дж. Р. - М. : Профико, 1991. $448 \mathrm{c}$.

4. Мишкін Ф. С. Економіка грошей, банківської справи і фінансових ринків / Ф. С. Мишкін ; пер. $з$ англ. С. Панчишина. - К. : Основи, 1998. -963 с.

\section{*УДК 657.1}

Чудовець В.В., к.е.н., доцент

Якимчук Д.Д.

Луцький національний технічний університет

\section{ЕКОНОМЕТРИЧНИЙ АНАЛІЗ ЗМІНИ ПОКАЗНИКІВ ДІЯЛЬНОСТІ СІЛЬСЬКОГОСПОДАРСЬКИХ ПІДПРИЄМСТВ ВНАСЛІДОК ПЕРЕОЦІНКИ ОСНОВНИХ ЗАСОБІВ}

У статті досліджено зв'язок між сумою залишкової вартості основних засобів і собівартістю реалізованої продукції сільськогосподарського підприємства. Використовуючи методи економетричного аналізу, визначено залежність між залишковою вартістю основних засобів та собівартістю реалізованої продукції підприємства. На основі отриманих результатів розраховано ймовірні відхилення між реальними показниками звітності та розрахунковими.

Ключові слова: справедлива вартість, переоцінка активів, фінансові результати.

* Чудовець В.В., Якимчук Д.Д. 